\title{
CALMODULIN STIMULATES ADENYLATE CYCLASE ACTIVITY AND INCREASES DOPAMINE ACTIVATION IN BOVINE RETINA ${ }^{1}$
}

\author{
MARGARET E. GNEGY, ${ }^{2}$ NANCY MUIRHEAD, JILL M. ROBERTS-LEWIS, ${ }^{*}$ AND \\ GLENN TREISMAN
}

Department of Pharmacology, University of Michigan Medical School, and * Department of Psychology, Psychobiology Program, University of Michigan, Ann Arbor, Michigan 48109

Received December 27, 1983; Accepted April 12, 1984

\begin{abstract}
Adenylate cyclase activity in bovine retina is highly responsive to $\mathrm{Ca}^{2+}$ and the endogenous $\mathrm{Ca}^{2+}$-binding protein, calmodulin $(\mathrm{CaM})$. CaM stimulated adenylate cyclase activity in washed particulate fractions of bovine retina by 6.6 -fold in a $\mathrm{Ca}^{2+}$-dependent manner. Activation of adenylate cyclase activity by $\mathrm{CaM}$ was maximal at $0.12 \mu \mathrm{M}$ free $\mathrm{Ca}^{2+}$. The apparent $\mathrm{K}_{\mathrm{a}}$ for calmodulin stimulation of adenylate cyclase was $67 \mathrm{nM}$ and the apparent $V_{\max }$ was $116 \mathrm{pmol} / \mathrm{min} / \mathrm{mg}$ of protein above basal activity. Adenylate cyclase activity in bovine retina was stimulated approximately $50 \%$ by guanosine $5^{\prime}$-triphosphate (GTP), but the nonhydrolyzable GTP analogue, guanosine- $5^{\prime}-(\beta, \gamma$-imido)triphosphate $(\mathrm{Gpp}(\mathrm{NH}) \mathrm{p})$, was able to activate the enzyme nearly 5 -fold. $\mathrm{CaM}$ and $\mathrm{Gpp}(\mathrm{NH}) \mathrm{p}$ appeared to be partially competitive activators of adenylate cyclase in the retina particulate fraction. Dopamine stimulated adenylate cyclase activity in the presence of GTP with an apparent $K_{a}$ of 1.0 $\mu \mathrm{M}$ and an apparent $V_{\max }$ of $66 \mathrm{pmol} / \mathrm{min} / \mathrm{mg}$ of protein. $\mathrm{Ca}^{2+}$ and CaM increased the apparent $V_{\max }$ of the dopamine-stimulated adenylate cyclase activity more than 2 -fold to a level of $146 \mathrm{pmol} / \mathrm{min} / \mathrm{mg}$ of protein but did not alter the apparent $\mathrm{K}_{\mathrm{a}}$. This suggests that $\mathrm{CaM}$ is an endogenous modulator of dopamine-stimulated adenylate cyclase activity in the retina. CaM-stimulated adenylate cyclase activity may be a common component to retina since we found this activity in retinas from rabbit, rat, and goldfish as well as cow.
\end{abstract}

It is well established that $\mathrm{Ca}^{2+}$ and cAMP are interrelated second messengers for many hormones and neurotransmitters (Rasmussen and Goodman, 1977). In a variety of tissues, $\mathrm{Ca}^{2+}$ increases cAMP synthesis and/or degradation by binding to the endogenous $\mathrm{Ca}^{2+}$-binding protein, calmodulin $(\mathrm{CaM})$, and increasing adenylate cyclase or phosphodiesterase activities (Cheung, 1980). $\mathrm{Ca}^{2+}$ - and CaM-stimulated adenylate cyclase activity is located primarily in brain (Cheung, 1980) but has also been reported in secretory tissues such as the pituitary (Brostrom et al., 1982) and pancreatic islets (Valverde et al., 1979). Two components of adenylate cyclase activity have been identified in areas of the brain such as striatum (Treisman et al., 1983) and cerebral cortex (Brostrom et al., 1977). One component can be activated by submicromolar concentrations of free $\mathrm{Ca}^{2+}$ and $\mathrm{CaM}$, whereas the other component is insensitive to $\mathrm{CaM}$ and inhibited by concentrations of free $\mathrm{Ca}^{2+}$ greater than $1 \mu \mathrm{M}$. There is significant evidence suggesting a role for $\mathrm{CaM}$ in modulating dopaminergic activity in rat striatum (Gnegy, 1982). In this tissue, CaM not only can stimulate basal adenylate cyclase activity but also can increase the sen-

\footnotetext{
${ }^{1}$ We would like to thank Dr. Michael luvone and Dr. Richard Neubig for their helpful discussions and advice concerning this work. The assistance of Lynn Iwaniec, Lisa Goring, and Linda Harbison in preparation of the manuscript is gratefully acknowledged. This work was supported by Grant RO1 MH36044-01 from the National Institute of Mental Health.

${ }^{2}$ To whom correspondence and reprint requests should be addressed.
}

sitivity of adenylate cyclase for dopamine (DA) by 3- to 4-fold (Gnegy and Treisman, 1981). Similarly, other studies have demonstrated a relationship between CaM content and DAstimulated adenylate cyclase activity in striatum and dopaminergic hyper- and hyporesponsive states (Hanbauer et al., 1980; Gnegy, 1982).

In an effort to explore further a relationship between CaMand DA- stimulated adenylate cyclase we have investigated these activities in bovine retina. Retina is a neural tissue with relatively few cell types. Neural retina contains a high concentration of DA that is located primarily in certain groups of amacrine cells or interplexiform cells, depending on the species (Lolley, 1980). DA-stimulated adenylate cyclase activity has been measured in homogenate (Watling and Dowling, 1981) or membrane fractions (Clement-Cormier and Redburn, 1978; Redburn et al., 1980) as well as intact retina (Brown and Makman, 1972) of several species. The postsynaptic DA receptors in the retina are predominantly coupled to a stimulation of adenylate cyclase activity (D-1 receptors) (Schorderet, 1977; Watling et al., 1979). Recently, however, the presence of D-2 receptor-binding sites has been identified in mammalian retina (Makman et al., 1980; Watling and Iversen, 1981). The presence of a $\mathrm{Ca}^{2+}$-dependent adenylate cyclase activity has been demonstrated indirectly in mammalian retina (DeVries et al., 1982; Ferrendelli et al., 1982). In these studies it was shown that the chelating agent EGTA can inhibit basal adenylate cyclase activity in retina, suggesting the presence of a $\mathrm{Ca}^{2+}$-activated adenylate cyclase activity. We have examined the stimulation 
of adenylate cyclase activity in bovine retina by $\mathrm{Ca}^{2+}$ and $\mathrm{CaM}$, as well as by guanyl nucleotides and DA. Guanyl nucleotides bind to a guanyl nucleotide-binding protein $(\mathrm{N})$ in membranes which then acts as the transducer for receptor-adenylate cyclase-coupled systems (Rodbell, 1980). Guanyl nucleotides are required for DA stimulation of adenylate cyclase activity (Gnegy and Treisman, 1981). Interactions between guanyl nucleotides and CaM have been reported in both striatum and cerebral cortex (Brostrom et al., 1978; Treisman et al., 1983), although evidence suggests that $\mathrm{CaM}$ acts at the catalytic subunit (C) of adenylate cyclase (Salter et al., 1981). An effect of CaM on DA-stimulated adenylate cyclase could occur through an interaction of $\mathrm{CaM}$ and guanyl nucleotides; therefore, we studied the activation of adenylate cyclase in the presence of both the guanyl nucleotides and CaM.

We found that adenylate cyclase activity in bovine retina is highly responsive to $\mathrm{CaM}$; CaM can stimulate adenylate cyclase activity at least 6 - to 7 -fold in a $\mathrm{Ca}^{2+}$-dependent manner. Many characteristics of the CaM-sensitive adenylate cyclase activity in bovine retina are very similar to those in bovine and rat striatum and cerebral cortex. Our data further demonstrate that CaM was able to increase the maximal velocity of DAstimulated adenylate cyclase activity more than 2-fold, suggesting that $\mathrm{CaM}$ is an endogenous modulator of DA-stimulated adenylate cyclase activity in retina.

\section{Materials and Methods}

Particulate preparation. Bovine eyes were obtained from the local slaughterhouse and retinas were removed within $15 \mathrm{~min}$ of the animals' deaths. Retinas were dissected free from the sclera at $4^{\circ} \mathrm{C}$, as described by Watling and Iversen (1981), taking care to tease the retina from the pigment epithelium. Retinal particulate fractions depleted of $\mathrm{Ca}^{2+}$ and CaM were prepared as described (Gnegy and Treisman, 1981), in a modification of the method of Brostrom et al. (1978). Briefly, retinas were homogenized in $9 \mathrm{vol}$ of $10 \mathrm{mM}$ Tris maleate buffer, $\mathrm{pH} 7.5$, containing $1 \mathrm{mM} \mathrm{MgSO}$ and $1.2 \mathrm{mM}$ EGTA. The homogenate fraction was centrifuged at $27,000 \times g$ for $20 \mathrm{~min}$, resuspended in the same buffer, and centrifuged a second time at $27,000 \times \mathrm{g}$. The pellet resulting from the final centrifugation was resuspended in $10 \mathrm{mM}$ Tris maleate buffer, $\mathrm{pH} 7.5$, containing $1.2 \mathrm{~mm}$ EGTA and $1 \mathrm{~mm} \mathrm{MgSO}$. Protein content was determined by the method of Lowry et al. (1951).

Adenylate cyclase assay. Adenylate cyclase activity was measured in an assay (200- $\mu 1$ volume) containing: $80 \mathrm{mM}$ Tris maleate buffer, $\mathrm{pH}$ $7.5,5 \mathrm{mM} \mathrm{MgSO}_{4}, 2 \mathrm{mM}$ cAMP, $4 \mathrm{mM}$ phosphenolpyruvate, $20 \mu \mathrm{g}$ of pyruvate kinase, $0.12 \mathrm{mM}$ isobutylmethylxanthine, 100 to $150 \mu \mathrm{g}$ of particulate membrane protein, $0.15 \mathrm{mM}$ EGTA, and $1 \mathrm{mM}\left[\alpha{ }^{32} \mathrm{P}\right] \mathrm{ATP}$ ( $1 \mu \mathrm{Ci}$ /assay), with or without additions such as guanosine- $5^{\prime}-(\beta, \gamma-$ imido)triphosphate $(\mathrm{Gpp}(\mathrm{NH}) \mathrm{p})$, guanosine $5^{\prime}$-triphosphate (GTP), $\mathrm{CaCl}_{2}$, and CaM. Assays were incubated for $10 \mathrm{~min}$ and the reaction was stopped by heating for $1 \mathrm{~min}$ at $95^{\circ} \mathrm{C}$. A solution $(200 \mu \mathrm{l})$ containing $20 \mathrm{~mm}$ ATP and $0.7 \mathrm{mM}\left[{ }^{3} \mathrm{H}\right] \mathrm{cAMP}$ was then added to the tubes. The particulate material was centrifuged and the ${ }^{32} \mathrm{P}$-labeled cAMP in the supernatant fraction was determined by the method of Krishna et al. (1968). Recovery of the cAMP was measured using the $\left[{ }^{3} \mathrm{H}\right] \mathrm{cAMP}$ and was usually 80 to $90 \%$. Free or effective concentrations of $\mathrm{Ca}^{2+}$ were calculated using a dissociation constant for Ca-EGTA of $4.08 \times 10^{-8} \mathrm{M}$ according to the method of Nanninga and Kempen (1971). Our calculations for free $\mathrm{Ca}^{2+}$ were verified on a computer program graciously provided by Dr. John Dedman, University of Texas Health Science Center (Houston, TX). Kinetic constants were determined by the method of Wilkinson (1961).

CaM preparation. CaM was purified from bovine brain by the method of Dedman et al. (1977) and demonstrated a single band on disc gel electrophoresis containing $10 \%$ polyacrylamide. CaM was prepared in the presence of millimolar concentrations of EGTA, dialyzed against $0.05 \mathrm{M}\left(\mathrm{NH}_{4}\right) \mathrm{HCO}_{3}$, and lyophilized. The CaM was redissolved in 10 mM Tris maleate buffer, $\mathrm{pH}$ 7.5. The protein concentration was determined by UV absorption (Dedman et al., 1977) and the method of Lowry et al. (1951). The molecular weight determined by sodium dodecyl sulfate slab gel electrophoresis using standards of known molecular weight was 16,700 . This mass was used to calculate the concentrations of CaM reported in this study.
Determination of CaM content. CaM was assayed by its ability to stimulate CaM-deficient phosphodiesterase activity in the phosphodiesterase assay described previously (Gnegy et al., 1977). The CaM content (in nanograms) was determined from a standard curve using highly purified CaM.

Materials. Bovine eyes were obtained fresh from a local slaughterhouse. [ $\left.\alpha{ }^{32} \mathrm{P}\right] \mathrm{ATP}$ (specific activity, $38 \mathrm{Ci} / \mathrm{mmol}$ ) was purchased from Amersham Searle Corp. (Arlington Heights, IL). cAMP, phosphoenolpyruvate, ATP, and 3-hydroxytyramine hydrochloride (dopamine, DA) were obtained from Sigma Chemical Co. (St. Louis, MO); pyruvate kinase was from Boehringer Mannheim (Indianapolis, IN). GTP and $\mathrm{Gpp}(\mathrm{NH}) \mathrm{p}$ (high pressure liquid chromatography purified) were purchased from International Chemical and Nuclear Corp. (Irvine, CA).

\section{Results}

CaM content in retinal particulate and cytosolic fractions. The CaM content as measured by phosphodiesterase activation in the cytosolic and particulate fractions prepared from bovine retina is shown in Table I. Bovine retina contained CaM in both fractions in concentrations comparable to that found in brain (Gnegy et al., 1977; Gnegy and Treisman, 1981). The data demonstrate that $\mathrm{CaM}$ was nearly twice as concentrated in the $27,000 \times g$ cylosolic fraction (11.4 $\mathrm{ng}$ of $\mathrm{CaM} / \mu \mathrm{g}$ of protein) as in the particulate fraction $(5.9 \mathrm{ng}$ of $\mathrm{CaM} / \mu \mathrm{g}$ of protein). Upon consideration of the total CaM content in the fractions it can be seen that $\mathrm{CaM}$ was equally distributed between the cytosolic and particulate fractions, which is virtually the same distribution that is found in brain (Gnegy et al., 1977).

Stimulation of retinal adenylate cyclase activity by $\mathrm{Ca}^{2+}$ and CaM. Particulate fractions washed with EGTA from whole bovine retina were used in all subsequent experiments. Depletion of endogenous $\mathrm{Ca}^{2+}$ and $\mathrm{CaM}$ from membranes is required in order to observe the effects of directly restoring $\mathrm{CaM}$. We found that 60 to $70 \%$ of the endogenous $\mathrm{CaM}$ was removed by the washing procedure. The ability of $\mathrm{CaM}$ to stimulate adenylate cyclase in the retinal particulate fractions depeleted of $\mathrm{Ca}^{2+}$ and $\mathrm{CaM}$ was determined. The activation of bovine retinal adenylate cyclase by $\mathrm{CaM}$ as a function of free $\mathrm{Ca}^{2+}$ is shown in Figure 1. Basal adenylate cyclase activity was $26 \pm 3$ (SEM) $\mathrm{pmol} / \mathrm{min} / \mathrm{mg}$ of protein. The adenylate cyclase activity was highly responsive to $\mathrm{CaM}$ and dependent upon $\mathrm{Ca}^{2+} . \mathrm{Ca}^{2+}$ itself could stimulate adenylate cyclase activity in the washed particulate fraction 2.0 -fold to a level of $50 \mathrm{pmol} / \mathrm{min} / \mathrm{mg}$ of protein. However, in the presence of $280 \mathrm{nM}$ CaM, a 6.6 -fold stimulation was attained, reaching a maximum of $145 \mathrm{pmol}$ of cAMP formed $/ \mathrm{min} / \mathrm{mg}$ of protein. The concentration of free $\mathrm{Ca}^{2+}$ at which CaM could maximally stimulate adenylate cyclase activity was $0.12 \mu \mathrm{M}$. The stimulation of the enzyme by $\mathrm{CaM}$ did not increase beyond this $\mathrm{Ca}^{2+}$ concentration and was inhibited by $30 \%$ with increasing concentrations of free $\mathrm{Ca}^{2+}$. The basal

\section{TABI, I}

CaM content in fractions from bovine retina

Retina was homogenized in 9 vol of $10 \mathrm{~mm}$ Tris maleate buffer, $\mathrm{pH} 7.5$, containing $1 \mathrm{mM} \mathrm{MgSO}_{4}$. Particulate fractions were prepared from homogenate fractions as described under "Materials and Methods" using the above buffer. CaM content was determined as described under "Materials and Methods." Results are given as values \pm SEM for three separate experiments.

\begin{tabular}{lcc}
\hline \multirow{2}{*}{ Fraction } & \multicolumn{2}{c}{ CaM Content } \\
\cline { 2 - 3 } & Concentration & Total CaM \\
\hline & $\mu g / m g$ of & membrane \\
protein & mg/gm of tissue \\
& $5.5 \pm 0.6$ & $427 \pm 32$ \\
Homogen weight & \\
Particulate & $5.9 \pm 1.0$ & $210 \pm 22$ \\
Soluble & $11.4 \pm 1.5$ & $243 \pm 30$ \\
\hline
\end{tabular}




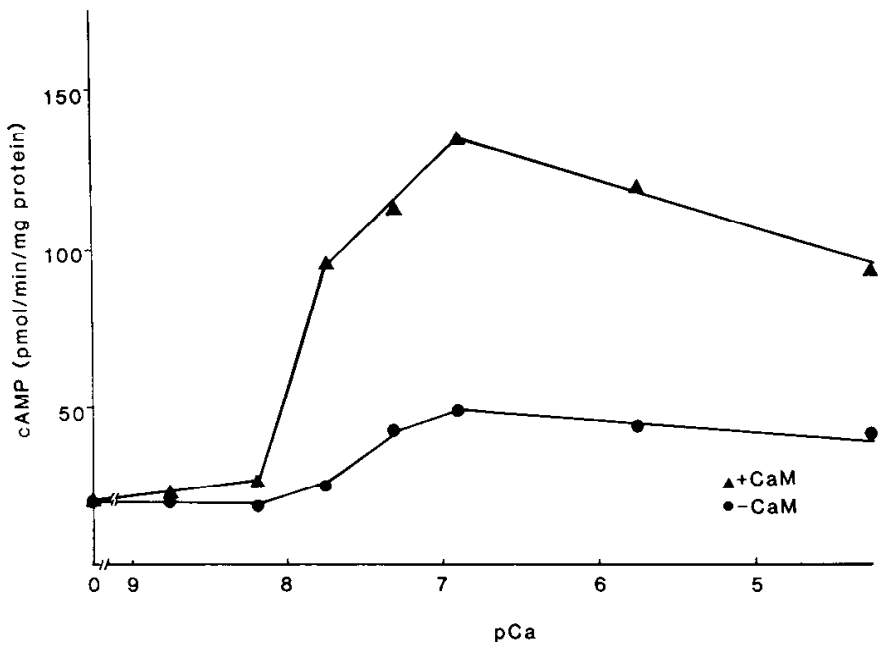

Figure 1. Effects of calcium and CaM on basal adenylate cyclase activity in bovine retinal particulate fractions. Adenylate cyclase assays were performed in an EGTA-washed retinal particulate fraction as described under "Materials and Methods" with $(\mathbf{\Delta})$ and without (-) the addition of $280 \mathrm{nM}$ highly purified CaM. The concentration of free $\mathrm{Ca}^{2+}$ was determined as described under "Materials and Methods." Each point is the average of duplicate determinations from two different experiments that did not vary by more than $5 \%$.

adenylate cyclase activity, however, was unaffected by increasing free $\mathrm{Ca}^{2+}$ to a level of $200 \mu \mathrm{M}$, a concentration that greatly inhibits adenylate cyclase activity in striatum (Gnegy and Treisman, 1981).

The concentration dependence for $\mathrm{CaM}$ in activation of bovine retina adenylate cyclase is illustrated in Figure 2. Activation of the cyclase is maximal at $560 \mathrm{nM} \mathrm{CaM}$, at a level of $150 \mathrm{pmol} / \mathrm{min} / \mathrm{mg}$ of protein. The apparent $\mathrm{K}_{\mathrm{a}}$ for CaM activation was $64 \pm 7 \mathrm{nM}(N=3)$. The apparent $V_{\max }$ for the stimulation of adenylate cyclase by CaM above basal activity was $116 \pm 8 \mathrm{pmol} / \mathrm{min} / \mathrm{mg}$ of protein $(N=3)$.

The occurrence of CaM-stimulated adenylate cyclase activity was not unique to bovine retina. We found that a maximal concentration of $1.4 \mu \mathrm{M} \mathrm{CaM}$, in the presence of $0.12 \mu \mathrm{M}$ free $\mathrm{Ca}^{2+}$, could stimulate adenylate cyclase activity in several species to the following degrees: rat, 5.2-fold; rabbit, 3 -fold; and goldfish, 6 -fold.

Effect of guanyl nucleotides on adenylate cyclase activity in the bovine retina particulate preparation. GTP stimulates basal adenylate cyclase activity in many tissues and is required for hormone and neurotransmitter activation of the enzyme through its interaction with the GTP-binding protein, N (Rodbell, 1980). We examined the ability of GTP and its nonhydrolyzable analogue, $\operatorname{Gpp}(\mathrm{NH}) \mathrm{p}$, to activate adenylate cyclase activity in particulate preparations of bovine retina. As the data in Table II demonstrate, GTP was not a potent activator of retinal adenylate cyclase activity. GTP stimulated basal adenylate cyclase activity maximally by only $53 \%$. Stimulation was no greater at $100 \mu \mathrm{M}$ GTP than at $10 \mu \mathrm{M}$ GTP. CaM and $\mathrm{Ca}^{2+}$ did not significantly alter the response to GTP; $10 \mu \mathrm{M}$ GTP was required to measure significant activation by GTP in the presence of $\mathrm{Ca}^{2+}$ and CaM. The activation by the two agents did not appear to be interactive, suggesting that they stimulate adenylate cyclase activity independently.

In contrast to the weak stimulation afforded by GTP, the nonhydrolyzable analogue of GTP, Gpp $(\mathrm{NH}) \mathrm{p}$, stimulated adenylate cyclase activity maximally by 4.8 -fold (Fig. 3 ). The $\mathrm{Gpp}(\mathrm{NH}) \mathrm{p}$ activation curve was biphasic; maximal activity occurred at $100 \mu \mathrm{M} \mathrm{Gpp}(\mathrm{NH}) \mathrm{p}$ but decreased at $1 \mathrm{mM}$. Kinetic analysis of the activation portion of the curve revealed an apparent $\mathrm{K}_{\mathrm{a}}$ for $\mathrm{Gpp}(\mathrm{NH}) \mathrm{p}$ of $3.5 \pm 0.9 \mu \mathrm{M}$ and an apparent $V_{\max }$ of $117 \pm 5 \mathrm{pmol} / \mathrm{min} / \mathrm{mg}$ of protein for cAMP formed above basal activity $(N=4)$. Adenylate cyclase activity in the presence of $\mathrm{CaM}$ and $\mathrm{Gpp}(\mathrm{NH}) \mathrm{p}$ was not purely additive at every concentration of $\mathrm{Gpp}(\mathrm{NH}) \mathrm{p}$ (Fig. 3). Activation by 280 $\mathrm{nM} \mathrm{CaM}$ was greatest at concentrations of $\mathrm{Gpp}(\mathrm{NH}) \mathrm{p}$ from 0 to $1 \mu \mathrm{M}$; at these concentrations $\mathrm{CaM}$ stimulated adenylate cyclase activity by approximately 114 to $96 \mathrm{pmol} / \mathrm{min} / \mathrm{mg}$ of protein above basal levels. At $100 \mu \mathrm{M} \mathrm{Gpp}(\mathrm{NH}) \mathrm{p}$, however, the stimulation produced by $\mathrm{CaM}$ above that of $\mathrm{Gpp}(\mathrm{NH}) \mathrm{p}$ was 70 $\mathrm{pmol} / \mathrm{min} / \mathrm{mg}$ of protein. Similarly, CaM appeared to decrease the extent of stimulation of adenylate cyclase activity by $\mathrm{Gpp}(\mathrm{NH}) \mathrm{p}$. In the presence of $280 \mathrm{nM} \mathrm{CaM}$, there was no significant activation by $\mathrm{Gpp}(\mathrm{NH}) \mathrm{p}$ below $100 \mu \mathrm{M} \mathrm{Gpp}(\mathrm{NH}) \mathrm{p}$ in contrast to the significant stimulation by 1 to $10 \mu \mathrm{M}$ $\mathrm{Gpp}(\mathrm{NH}) \mathrm{p}$ apparent in the absence of CaM. The amount of activation by $100 \mu \mathrm{M} \mathrm{Gpp}(\mathrm{NH}) \mathrm{p}$ was reduced in the presence of CaM from 114 to $78 \mathrm{pmol} / \mathrm{min} / \mathrm{mg}$ of protein for cAMP above basal levels. The results suggest that, although both $\mathrm{CaM}$ and $\mathrm{Gpp}(\mathrm{NH}) \mathrm{p}$ can activate retinal adenylate cyclase activity, they appear to have a partially competitive rather than a strictly additive interaction.

$D A$-stimulated adenylate cyclase activity in bovine retina. The effect of $\mathrm{Ca}^{2+}$ and CaM on DA-stimulated adenylate cyclase

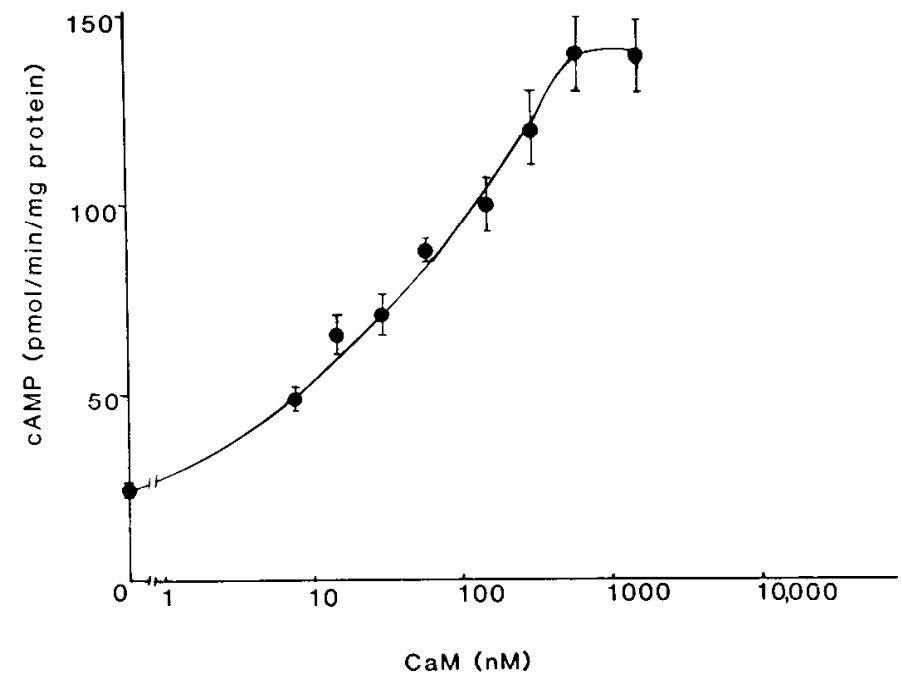

Figure 2. Activation of bovine retina adenylate cyclase by CaM. Adenylate cyclase activity was assayed in an EGTA-washed particulate fraction as described under "Materials and Methods." All assays with CaM contained $0.12 \mu \mathrm{M}$ free $\mathrm{Ca}^{2+}\left(100 \mu \mathrm{M}\right.$ added $\left.\mathrm{CaCl}_{2}\right)$. Each point is the average of four separate experiments \pm SEM.

TABLE II

Stimulation of bovine relina adenylate cycluse aclivity by GTP and CaM

\begin{tabular}{|c|c|c|}
\hline \multicolumn{3}{|c|}{ Adenylate Cyclase Activity } \\
\hline GTP & $-\mathrm{CaM}$ & $+\mathrm{CaM}^{a}$ \\
\hline$\mu M$ & \multicolumn{2}{|c|}{ 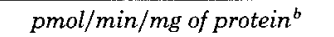 } \\
\hline 0 & $34 \pm 5$ & $108 \pm 5$ \\
\hline 0.1 & $40 \pm 4$ & $100 \pm 4$ \\
\hline 1.0 & $42 \pm 3$ & $111 \pm 7$ \\
\hline 10.0 & $52 \pm 6^{c}$ & $127 \pm 3^{c}$ \\
\hline
\end{tabular}

${ }^{a}$ The assay contained $280 \mathrm{nM} \mathrm{CaM}$ and $0.12 \mu \mathrm{M}$ free $\mathrm{Ca}^{2+}(100 \mu \mathrm{M}$ added $\mathrm{CaCl}_{2}$ ).

${ }^{b}$ Results are given as picomoles per minute per milligram of protein \pm SEM for four separate experiments.

${ }^{c} p<0.05$ as compared to value for no GTP within the respective group. 


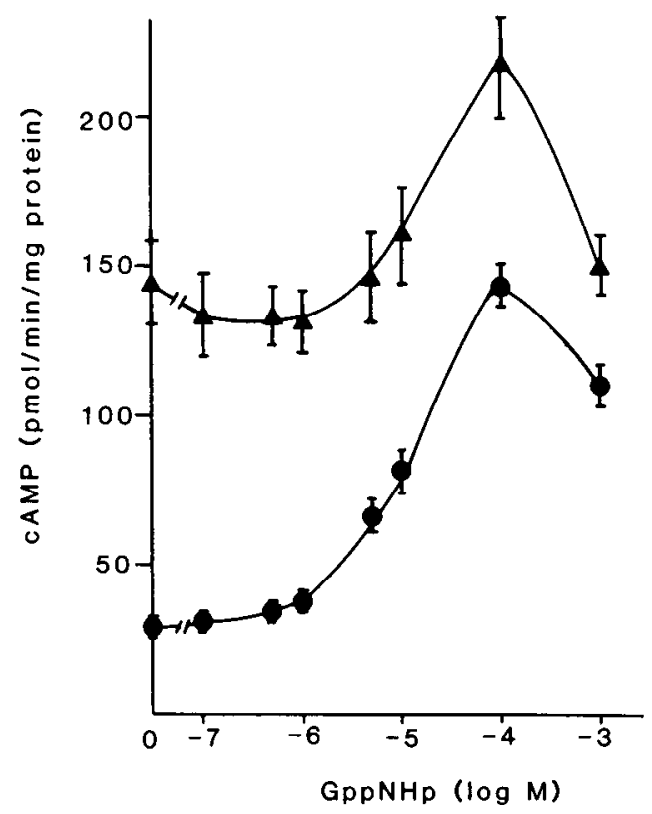

Figure 3. Activation of bovine retina adenylate cyclase by $\mathrm{Gpp}(\mathrm{NH}) \mathrm{p}$ in the absence and presence of $\mathrm{Ca}^{2+}$ and CaM. A bovine retina particulate fraction was prepared and adenylate cyclase was assayed as described under "Materials and Methods." The concentration dependence to $\mathrm{Gpp}(\mathrm{NH}) \mathrm{p}$ was measured in the absence (O) and presence (A) of $0.12 \mu \mathrm{M} \mathrm{Ca}^{2+}\left(100 \mu \mathrm{M} \mathrm{CaCl}_{2}\right.$ added in the assay) and $280 \mathrm{nM}$ CaM. The results are the average of four separate experiments \pm SEM. activity in the bovine retina particulate fraction was examined. In the EGTA-washed retinal particulate preparations, GTP was required for stimulation of adenylate cyclase activity by DA. The stimulation of adenylate cyclase activity by various concentrations of DA in the retinal particulate fractions in the absence and presence of $\mathrm{CaM}$ is shown in Figure 4. Activation of adenylate cyclase in the presence of $1 \mu \mathrm{M}$ GTP was maximal at $100 \mu \mathrm{M} \mathrm{DA}$. The activation of adenylate cyclase in the presence of GTP, DA, and $280 \mathrm{nM}$ CaM was greater than additive (Fig. $4 A$ ). Thus, DA was able to stimulate the production of more cAMP in the presence, as opposed to the absence, of $\mathrm{Ca}^{2+}$ and $\mathrm{CaM}$. This is shown more clearly by the data in Figure $4 B$, which depict the DA-stimulated adenylate cyclase activity. DA-stimulated adenylate cyclase activity was defined as the picomoles of cAMP per minute per milligram of protein formed above the activity in the presence of GTP alone. Kinetic analysis revealed that $\mathrm{CaM}$ significantly increased the maximal velocity of the DA-stimulated adenylate cyclase activity. In the absence of $\mathrm{Ca}^{2+}$ and $\mathrm{CaM}$, the apparent $\mathrm{K}_{\mathrm{a}}$ for DA was $1.0 \pm$ $0.3 \mu \mathrm{M}$ and the apparent $V_{\max }$ was $66 \pm 4 \mathrm{pmol} / \mathrm{min} / \mathrm{mg}$ of protein $(N=4)$. The apparent $\mathrm{K}_{\mathrm{a}}$ for DA was not significantly affected by addition of $\mathrm{Ca}^{21}$ and $\mathrm{CaM}$ and was $1.3 \pm 0.4 \mu \mathrm{M}(N$ $=4)$. However, the apparent $V_{\max }$ of the DA-stimulated adenylate cyclase activity was significantly increased more than 2fold by CaM to $146 \pm 15 \mathrm{pmol} / \mathrm{min} / \mathrm{mg}$ of protein $(p<0.01$, as compared to the value obtained in the absence of $\mathrm{CaM})$.

\section{Discussion}

The highest concentration of $\mathrm{CaM}$ - and $\mathrm{Ca}^{2+}$-stimulated adenylate cyclase activity occurs in brain, although CaM has

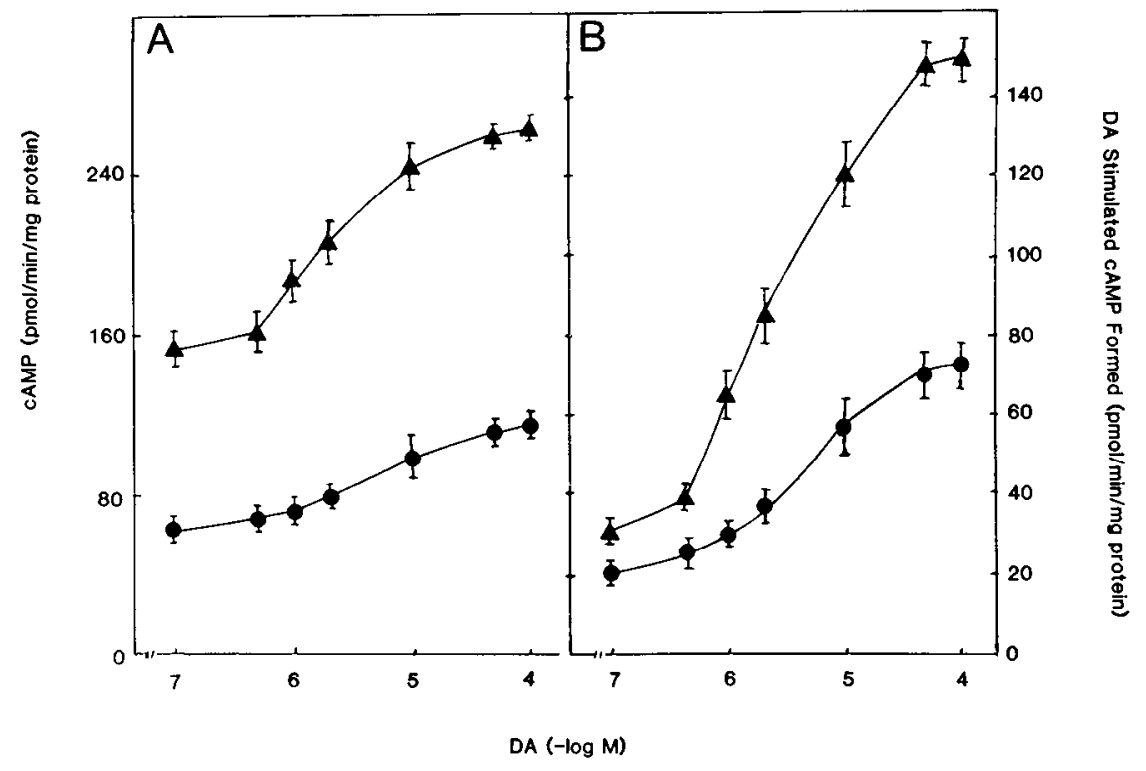

Figure 4. A, Activation of retinal adenylate cyclase by DA in the absence and presence of $\mathrm{Ca}^{2+}$ and $\mathrm{CaM}$. Adenylate cyclase activity was measured in a washed particulate fraction as described under "Materials and Methods." Each assay contained $1 \mu \mathrm{M}$ GTP and various concentrations of DA in the absence $(\bullet)$ and presence $(\Delta)$ of $0.12 \mu \mathrm{M}$ free $\mathrm{Ca}^{2+}\left(100 \mu \mathrm{M}\right.$ added $\left.\mathrm{CaCl}_{2}\right)$ and $280 \mathrm{nM}$ CaM. For adenylate cyclase, activity in the presence of $1 \mu \mathrm{M}$ GTP and GTP $+\mathrm{Ca}^{2+}$ and $\mathrm{CaM}$ was $42 \pm 3$ and $122 \pm 13 \mathrm{pmol} / \mathrm{min} /$ $\mathrm{mg}$ of protein, respectively. Each point is the average of four separate experiments \pm SEM. $B$, Effect of $\mathrm{Ca}^{2+}$ and CaM on DA-stimulated adenylate cyclase activity in rat particulate fractions. DA-stimulated adenylate cyclase activity was defined as the picomoles of cAMP per minute per milligram of protein formed above the activity in the presence of GTP alone (-) or GTP plus $\mathrm{Ca}^{2+}$ and CaM (A). The DA-stimulated adenylate cyclase activity was calculated from the data presented in $A$. Each point is the average of four separate experiments \pm SEM. 
been reported to stimulate adenylate cyclase activity in several peripheral secretory tissues such as the pituitary and pancreatic islets (Brostrom et al., 1982; Valverde et al., 1979). In this report, we have demonstrated CaM-stimulated adenylate cyclase activity in another neural tissue, the retina. Our results demonstrate that adenylate cyclase activity in bovine retina is highly sensitive to CaM. In the presence of $\mathrm{Ca}^{2+}$, CaM could stimulate the enzyme 6.6-fold. The enzyme was significantly stimulated by DA and $\mathrm{Gpp}(\mathrm{NH}) \mathrm{p}$, whereas GTP was a weak activator. Furthermore, CaM affected the activation of adenylate cyclase by both $\mathrm{Gpp}(\mathrm{NH}) \mathrm{p}$ and $\mathrm{DA}$, demonstrating an interaction with these agents. CaM-stimulated adenylate cyclase activity is likely to exist in the retina of many species since we were able to measure 3- to 7-fold stimulation by CaM in bovine, rat, rabbit, and goldfish retina.

The characteristics of the activation of bovine retina adenylate cyclase by $\mathrm{CaM}$ are similar to those we reported previously in rat striatum (Gnegy and Treisman, 1981), although there appears to be more CaM-sensitive adenylate cyclase activity in retina as compared to CaM-insensitive adenylate cyclase activity. The stimulation by CaM was totally dependent upon the presence of $\mathrm{Ca}^{2+}$. Maximal activation by $\mathrm{CaM}$ was atlained at $0.12 \mu \mathrm{M}$ free $\mathrm{Ca}^{2+}$, which is the maximally effective concentration of $\mathrm{Ca}^{2+}$ for CaM activation found in rat striatum (Gnegy and Treisman, 1981) and rat cerebral cortex (Brostrom et al., 1977). Neither the basal adenylate cyclase activity nor the activation by $\mathrm{CaM}$ was strongly inhibited by high free $\mathrm{Ca}^{2+}$ in the retina, unlike the CaM activation in brain. In bovine retina, free $\mathrm{Ca}^{2+}$ itself was able to activate adenylate cyclase 2 -fold. This may reflect either an activation by endogenous CaM that could not be depleted from the membranes or a separate action of $\mathrm{Ca}^{2+}$ in stimulation of adenylate cyclase. The kinetic constants obtained for CaM-stimulated adenylate cyclase activity in bovine retina were very similar to those obtained in rat striatum. The apparent $\mathrm{K}_{\mathrm{a}} \mathrm{s}$ for $\mathrm{CaM}$ in activation of adenylate cyclase in retina and striatum are 67 and $70 \mathrm{nM}$ (Gnegy and Treisman, 1981), respectively. The apparent $V_{\max } \mathrm{s}$ are also similar in retina and striatum, 116 and $110 \mathrm{pmol} / \mathrm{min} / \mathrm{mg}$ of protein, respectively (Gnegy and Treisman, 1981), despite the fact that CaM stimulates adenylate cyclase 6.6-fold in the retina and 2 -fold in the striatum. Therefore, CaM-stimulated adenylate cyclase in retina has many characteristics similar to those in brain.

Our data demonstrated that CaM and DA could synergistically activate adenylate cyclase activity in retina. In the retinal particulate fractions, CaM increased the apparent $V_{\max }$ for DAstimulated adenylate cyclase activity more than 2 -fold but did not affect the apparent $K_{a}$ for DA. On the other hand, in rat striatum CaM could increase the affinity of adenylate cyclase for DA 3- to 4-fold but did not alter the apparent $V_{\max }$ for the reaction (Gnegy and Treisman, 1981). Therefore, the interaction of CaM with the components involved in DA-stimulated adenylate cyclase activity may be substantially different in retina from that in striatum. The molecular mechanism by which CaM affects basal or hormone-sensitive adenylate cyclase activity is unknown. Evidence suggests that CaM acts at the catalytic subunit in brain and does not require GTP for its activation (Salter et al., 1981; Heideman et al., 1982). Our results suggest that CaM and DA affect the same catalytic activity. CaM may increase an interaction between GTP-occupied $\mathrm{N}$ and $\mathrm{C}$ proteins in the retina. It is also possible that CaM could bind to a factor inhibitory to DA stimulation. A synergistic activation of adenylate cyclase by $\mathrm{CaM}$ and $\beta$ adrenergic agonists in bovine cerebellum has been reported (Malnoë et al., 1983), suggesting that CaM can similarly modulate the activity of other neurotransmitters in neural tissue.

Adenylate cyclase activity in bovine retina was also stimulated by guanyl nucleotides. GTP, the endogenous ligand for the. guanyl nucleotide-binding protein, could only minimally activate the adenylate cyclase as compared to the nonhydrolyzable analogue, $\mathrm{Gpp}(\mathrm{NH}) \mathrm{p}$. This could be because endogenous guanosine $5^{\prime}$-diphosphate (GDP) is very tightly bound to $\mathrm{N}$ protein and is unable to be displaced by GTP. DA is most likely stimulating a nucleotide exchange reaction between GDP and GTP at protein N (Cassel and Selinger, 1978). CaM did not appreciably affect the activation by GTP but did have a limited interaction with $\operatorname{Gpp}(\mathrm{NH}) \mathrm{p}$. CaM and $\operatorname{Cpp}(\mathrm{NH}) \mathrm{p}$ appeared to be partially competitive activators of adenylate cyclase, since one could decrease the activity of the other. CaM could act at a site on protein $\mathrm{C}$ that is affected by $\mathrm{Gpp}(\mathrm{NH}) \mathrm{p}$-occupied protein N. Another explanation for the fact that CaM blocks the adenylate cyclase activation by low concentrations of $\mathrm{Gpp}(\mathrm{NH}) \mathrm{p}$ is that $\mathrm{CaM}$ and $\mathrm{Ca}^{2+}$ could be activating another adenylate cyclase system responsive to an inhibitory $\mathrm{N}$ protein $\left(N_{i}\right)$ (Rodbell, 1980). Girardot et al. (1983) have shown that $\mathrm{Ca}^{2+}$ and $\mathrm{CaM}$ are required for inhibition of adenylate cyclase activity by guanyl nucleotides and hormones in rat hippocampal membranes. Thus, CaM may be able to affect both activation and inhibition of adenylate cyclase by hormones and guanyl nucleotides in neural tissue.

We do not know, of course, whether the CaM and DAstimulated adenylate cyclase activities are in the same cell types in the retina. DA is located primarily in a certain type of amacrine cell in the inner nuclear layer of the retina or in interplexiform cells in species such as the teleost fish (Lolley, 1980). DeVries et al. (1982) have shown that adenylate cyclase is located primarily in the inner plexiform and photoreceptor cell layers in the rabbit and ground squirrel. The adenylate cyclase activity in the inner plexiform layer of the retina was inhibited by EGTA, suggesting that this layer contains a $\mathrm{Ca}^{2+}$ activatable enzyme form. These investigators characterized the inner plexiform layer of rabbit and ground squirrel retina as containing an adenylate cyclase that is stimulated by $\mathrm{Ca}^{2+}$, $\mathrm{Gpp}(\mathrm{NH}) \mathrm{p}$, and DA. There were forms of adenylate cyclase in other layers which were not stimulated by $\mathrm{Ca}^{2+}$; indeed, EGTA stimulated these forms, suggesting that $\mathrm{Ca}^{2+}$ itself would be inhibitory.

In summary, we have identified a $\mathrm{Ca}^{2+}$ - and $\mathrm{CaM}$-stimulated adenylate cyclase in bovine retina as well as retina from other species. This adenylate cyclase may be identical to a DAstimulated adenylate cyclase since CaM can directly increase the $V_{\max }$ for DA. Our studies with $\mathrm{CaM}$ and $\mathrm{Gpp}(\mathrm{NH}) \mathrm{p}$ further suggest an interaction between $\mathrm{CaM}$ and guanyl nucleotides in the activation of adenylate cyclase. The evidence suggests that the CaM-stimulated adenylate cyclase can be stimulated to some extent by $\operatorname{Gpp}(\mathrm{NH}) \mathrm{p}$, and these agents may be partial competitive activators of the cyclase. Although $\mathrm{CaM}$ has also been shown to affect DA-stimulated adenylate cyclase activity in rat striatum, the molecular mechanism of this action may be different in retina. Preliminary studies in our laboratory further strengthen a relationship between $\mathrm{DA}-, \operatorname{Gpp}(\mathrm{NH}) \mathrm{p}-$, and CaM-stimulated adenylate cyclase activities in bovine retina by showing that these activities are similarly regulated by lighting conditions.

\section{References}

Brostrom, C. O., M. A. Brostrom, and D. J. Wolff (1977) Calciumdependent adenylate cyclase from rat cerebral cortex. Reversible activation by sodium fluoride. J. Biol. Chem. 252: 5677-5685.

Brostrom, M. A., C. O. Brostrom, and D. J. Wolff (1978) Calciumdependent adenylate cyclase from rat cerebral cortex: Activation by guanine nucleotides. Arch. Biochem. Biophys. 191: 341-350.

Brostrom, M. A., L. A. Brotman, and C. O. Brostrom (1982) Calciumdependent adenylate cyclase of pituitary tumor cells. Biochim. Biophys. Acta 721: 227-235.

Brown, J. H., and M. H. Makman (1972) Stimulation by dopamine of adenylate cyclase in retinal homogenates and adenosine $3^{\prime}: 5^{\prime}$-cyclic 
monophosphate formation in intact retina. Proc. Natl. Acad. Sci. U. S. A. 69: 539-543.

Cassel, P., and Z. Selinger (1978) Mechanism of adenylate cyclase activation through the $\beta$-adrenergic receptor: Catecholamine-induced displacement of bound GDP by GTP. Proc. Natl. Acad. Sci. U. S. A. 75: 4155-4159.

Cheung, W. Y. (1980) Calmodulin plays a pivotal role in cellular regulation. Science 207: 19-27.

Clement-Cormier, Y., and D. Redburn (1978) Dopamine-sensitive adenylate cyclase in retina-subcellular distribution. Biochem. Pharmacol. 27: 2281-2282.

Dedman, J. R., J. D. Potter, R. L. Jackson, J. D. Johnson, and A. R. Means (1977) Physicochemical properties of rat testis $\mathrm{Ca}^{2+}$ depend ent regulator protein of cyclic nucleotide phosphodiesterase. Relationship of $\mathrm{Ca}^{2+}$ binding, conformational changes, and phosphodiesterase activity. J. Biol. Chem. 252: 8415-8422.

DeVries, G. W., K. M. Campau, and J. A. Ferrendelli (1982) Adenylate cyclase in the vertebrate retina: Distribution and characteristics in rabbit and ground squirrel. J. Neurochem. 38: 759-765.

Ferrendelli, J. A., K. M. Campau, and G. W. DeVries (1982) Adenylate cyclase in vertebrate retina: Enzymatic characteristics in normal and dystrophic mouse retina. J. Neurochem. 38: 753-758.

Girardot, J. -M., J. Kempf, and D. M. F. Cooper (1983) Role of calmodulin in the effect of guanyl nucleotides on rat hippocampal adenylate cyclase: Involvement of adenosine and opiates. J. Neurochem. 41: 848-859.

Gnegy, M. E. (1982) Relationship of calmodulin and dopaminergic activity in the striatum. Fed. Proc. 41: 2273-2277.

Gnegy, M., and G. Treisman (1981) Effect of calmodulin on dopamine sensitive adenylate cyclase activity in rat striatal membranes. Mol. Pharmacol. 19: 256-263.

Gnegy, M. E., J. A. Nathanson, and P. Uzunov (1977) Release of the phosphodiesterase activator by cyclic AMP-dependent ATP: Protein phosphotransferase from subcellular fractions of rat brain. Biochim. Biophys. Acta 497: 75-85.

Hanbauer, I., S. Pradham, and H. -Y. T. Yang (1980) Role of calmodulin in dopaminergic transmission. Ann. N. Y. Acad. Sci. 356: 292-303.

Heideman, W., B. M. Wierman, and D. R. Storm (1982) GTP is not required for calmodulin stimulation of bovine brain adenylate cyclase. Proc. Natl. Acad. Sci. U. S. A. 79: 1462-1465.

Krishna, G., B. Weiss, and B. B. Brodie (1968) A simple, sensitive method for the assay of adenyl cyclase. J. Pharmacol. Exp. Ther. 163: 379-385.

Lolley, R. N. (1980) Cyclic nucleotide metabolism in the vertebrate retina. Curr. Top. Eye Res. 2: 67-118.

Lowry, O. H., N. J. Rosebrough, A. L. Farr, and R. J. Randall (1951)
Protein measurement with the Folin phenol reagent. J. Biol. Chem. 193: $265-275$

Makman, M. H., B. Dvorkin, S. G. Horowitz, and L. J. Thal (1980) Properties of dopamine agonist and antagonist binding sites in mammalian retina. Brain Res. 194: 403-418.

Malnoë, A., E. A. Stein, and J. A. Cox (1983) Synergistic activation of bovine cerebellum adenylate cyclase by calmodulin and $\beta$-adrenergic agonist. Neurochem. Int. 5: 65-72.

Nanninga, B., and R. Kempen (1971) Role of magnesium and calcium in the first and second contraction of glycerin-extracted muscle fibers. Biochemistry 10: 2449-2456.

Rasmussen, H., and D. B. P. Goodman (1977) Relationships between calcium and cyclic nucleotides in cell activation. Physiol. Rev. 57: 421-509.

Redburn, D. A., Y. Clement-Cormier, and D. M. K. Lam (1980) Dopamine receptors in the goldfish retina: ${ }^{3} \mathrm{H}$-Spiroperidol and ${ }^{3} \mathrm{H}$ domperidone binding; and dopamine-stimulated adenylate cyclase activity. Life Sci. 27:23-31.

Rodbell, M. (1980) The role of hormone receptors and G'I'P-regulatory proteins in membrane transduction. Nature 284: 17-22.

Salter, R. S., M. H. Krinks, C. B. Klee, and E. J. Neer (1981) Calmodulin activates the isolated catalytic unit of brain adenylate cyclase. J. Biol. Chem. 256: 9830-9833.

Schorderet, M. (1977) Pharmacological characterization of the dopamine-mediated accumulation of cyclic AMP in intact retina of rabbit. Life Sci. 20: 1741-1748.

Treisman, G. J., S. Bagley, and M. E. Gnegy (1983) Calmodulin sensitive and calmodulin-insensitive components of adenylate cyclase activity in rat striatum have differential responsiveness to guanyl nucleotides. J. Neurochem. 41: 1398-1406.

Valverde, I., A. Vandermeers, R. Anjaneyulu, and W. J. Malaisse (1979) Calmodulin activation of adenylate cyclase in pancreatic islets. Science 206: 225-227.

Watling, K. J., and J. E. Dowling (1981) Dopaminergic mechanisms in the teleost retina. I. Dopamine-sensitive adenylate cyclase in homogenates of carp retina; effects of agonists, antagonists and ergots. J. Neurochem. 36: 559-568.

Watling. K. J., and L. L. Iversen (1981) Comparison of the binding of $\left[{ }^{3} \mathrm{H}\right]$ spiperone and $\left[{ }^{3} \mathrm{H}\right]$ domperidone in homogenates of mammalian retina and caudate nucleus. J. Neurochem. 37: 1130-1143.

Watling, K. J., J. E. Dowling, and L. L. Iversen (1979) Dopamine receptors in the retina may be all linked to adenylate cyclase. Nature 281: $578-580$.

Wilkinson, G. N. (1961) Statistical estimations in enzyme kinetics. Biochem. J. 80: 324-332. 